\title{
Juvenile systemic sclerosis: review of 15 patients
}

\author{
Sandra I Sousa ${ }^{* *}$, Susana Fernandes ${ }^{2}$, Paula Estanqueiro ${ }^{3}$, Carla Zilhão ${ }^{4}$, Catarina Resende ${ }^{5}$, Filipa Ramos ${ }^{5}$, \\ Manuel Salgado ${ }^{3}$, Margarida Guedes ${ }^{4}$, José Melo Gomes ${ }^{2}$, Maria José Santos ${ }^{1}$ \\ From 21st European Pediatric Rheumatology (PReS) Congress \\ Belgrade, Serbia. 17-21 September 2014
}

\section{Introduction}

Introduction: Systemic sclerosis, a rare disease in childhood, is characterized by skin fibrosis, internal organ involvement, and vasculopathy. Juvenile systemic sclerosis (JSSc) represents less than $10 \%$ of all scleroderma patients.

\section{Objectives}

Objectives: To describe the clinical characteristics and disease progression of children with JSSc followed in Portuguese pediatric rheumatology centers.

\section{Methods}

Methods: Clinical and laboratory features as well as medication and outcome of children who met classification criteria for JSSc were reviewed.

\section{Results}

Results: Fifteen patients were identified and included in the analysis, 3 of them were overlap syndromes. Eleven girls $(73 \%), 13(87 \%)$ Caucasians, with a mean age at diagnosis of $11.1 \pm 3.0(3-15)$ years and a mean disease duration of $7.2 \pm 4.2$ years ( 8 months- 17 years). In 14 (93\%) cases, the first symptom attributable to JSSc was Raynaud's phenomenon, followed by arthritis and/or puffy hands (9 patients, 60\%). At disease diagnosis $12(80 \%)$ patients presented periungual capillaropathy and in 8 patients, pulmonary involvement was documented, despite the absence of respiratory complaints. Cumulative disease manifestations as well as complications developed during follow-up are shown in table 1.

All but one child were ANA positive (93\%), 7 tested positive for anti-Scl70, 2 positive for anti-RNP and 1 for anti-fibrillarin antibodies. There were no cases of anticentromere antibodies.

Immunosuppressants (93\%), proton pump inhibitors (80\%), calcium channel blockers (53\%) and corticosteroids $(60 \%)$ were the most common therapeutic options. Five and four children were treated with prostacyclin analogues and ET-1 receptor antagonist, respectively. One child needed autologous bone marrow transplant due to severe refractory disease.

An improvement of skin thickening and stabilization of pulmonary involvement was documented in most cases. No deaths were registered in this cohort. Table 1.

\section{Conclusion}

Conclusions: Diffuse cutaneous disease was the subtype of JSSc more prevalent identified in pediatric rheumatology centers. Raynaud's phenomenon as well as capillaroscopic abnormalities are almost universal at disease presentation. Internal organ involvement is common and occurs early during disease course, although clinically silent in several cases.

\section{Disclosure of interest}

None declared.

Table 1 Cumulative manifestations and complications observed during the follow-up

\begin{tabular}{cccccccc}
\hline $\begin{array}{c}\text { Diffuse cutaneous } \\
\text { disease }\end{array}$ & $\begin{array}{c}\text { Digital } \\
\text { ulcers }\end{array}$ & Calcinosis & $\begin{array}{c}\text { Musculoskeletal } \\
\text { involvement }\end{array}$ & $\begin{array}{c}\text { Interstitial lung } \\
\text { disease }\end{array}$ & $\begin{array}{c}\text { Cardiac } \\
\text { disease }\end{array}$ & $\begin{array}{c}\text { Gastrointestinal } \\
\text { disease }\end{array}$ & $\begin{array}{c}\text { Renal } \\
\text { disease }\end{array}$ \\
\hline $15(100 \%)$ & $11(73 \%)$ & $3(20 \%)$ & $13(87 \%)$ & $8(53 \%)$ & $2(13 \%)$ & $7(47 \%)$ & $1(7 \%)$ \\
\hline
\end{tabular}

${ }^{1}$ Rheumatology, Hospital Garcia de Orta, Almada, Portugal

Full list of author information is available at the end of the article 


\section{Authors' details}

${ }^{1}$ Rheumatology, Hospital Garcia de Orta, Almada, Portugal. ${ }^{2}$ Rheumatology, Instituto Português de Reumatologia, Lisboa, Portugal. ${ }^{3}$ Pediatrics, Hospital Pediátrico de Coimbra; , Coimbra, Portugal. ${ }^{4}$ Pediatrics, Hospital de Santo António, Porto, Portugal. ${ }^{5}$ Rheumatology, Hospital de Santa Maria, Lisboa, Portugal.

Published: 17 September 2014

doi:10.1186/1546-0096-12-S1-P118

Cite this article as: Sousa et al.: Juvenile systemic sclerosis: review of 15 patients. Pediatric Rheumatology 2014 12(Suppl 1):P118.

Submit your next manuscript to BioMed Central and take full advantage of:

- Convenient online submission

- Thorough peer review

- No space constraints or color figure charges

- Immediate publication on acceptance

- Inclusion in PubMed, CAS, Scopus and Google Scholar

- Research which is freely available for redistribution

Submit your manuscript at www.biomedcentral.com/submit
() Biomed Central 